\title{
Antioxidant activity of Clematis brachiata Thunb. leaf
}

\author{
M. Mostafa ${ }^{1 *}$, S. Ahmed ${ }^{1}$ and AJ Afolayan ${ }^{2}$ \\ ${ }^{1}$ BCSIR Laboratories, Dhaka-1205, Bangladesh \\ ${ }^{2}$ Center for Phytomedicine Research, Department of Botany, University of Fort Hare, Alice 5700, South Africa
}

Received: 17 August 2017

Revised: 02 October 2017

Accepted: 31 January 2018

DOI: http://dx.doi.org/10.3329/bjsir.v53i3.38264

\begin{abstract}
The antioxidant activity, total phenolic and flavonoid contents of different extracts of the Clematis brachiata Thunb leaves were determined. The antioxidant activity was evaluated using spectroscopic methods against 2,2-diphenyl-1-picrylhydrazyl radical (DPPH) and 2,2'-azinobis [3-ethylbenzothiazoline-6-sulphonic acid] diammonium salt radical cation (ABTS). Folin Ciocalteu method was used to determine the total phenolics and Aluminium Chloride Colorimetric method was used to determine the flavonoids contents in these extracts. The results showed that the methanol extract of the leaf exhibited the highest antioxidant activity with the value of $180.45 \pm 2.4 \mu \mathrm{g} \mathrm{mL}^{-1}$ in DPPH and $60 \pm 0.80 \mu \mathrm{g} \mathrm{mL}^{-1}$ in ABTS assay among the extracts. The methanol extract contains more phenolic compounds $(178 \pm 2.20 \mathrm{mg} / \mathrm{g}$ as galic acid equivalent per $\mathrm{g}$ dry matter) and the acetone extract contains more flavonoids $(135.11 \pm 1.20 \mathrm{mg} / \mathrm{g}$ as quercitin equivalent per $\mathrm{g}$ dry matter) among the extracts. This study provides the evidence that the leaves of the Clematis brachiata Thunb could be a good source of natural antioxidant.
\end{abstract}

Keywords: Clematis brachiata; Antioxidant activity; Phenolic; Flavonoid

\section{Introduction}

Medicinal plants are becoming more popular to the world of research as natural antioxidant sources because of their ability to detoxify free radicals from the biological system. Free radicals are capable of attacking the healthy cells of the body, causing them to lose their structure and function. Cell damage caused by free radicals appears to be a major contributor to aging and to degenerative diseases such as cancer, cardiovascular disease, cataracts, immune system decline and brain dysfunction (Cadenas, 2000). Fortunately, free radical formation is controlled naturally by various beneficial compounds known as antioxidants. Free radicals are electrically changed molecules i.e they have an unpaired electron, which causes them to seek out and capture electrons from other substances in order to neutralize themselves (Muthiah, 2012).

Antioxidants are compounds with the ability to protect a biological system against potentials harmful effects of processes or reactions involving reactive oxygen and nitrogen species (ROS and RNS) (Mishra et al., 2006) and they are natural disease preventing, health promoting and anti-ageing substances (Ozyurt et al, 2004). Phenolics are an important class of secondary plant metabolites possessing an impressive array of pharmacological activity. One of the more prominent properties of the phenolics is their excellent radical scavenging ability. Flavonoids are a group of polyphenolic compounds with known properties which include free radical scavenging, inhibition of hydrolytic and oxidative enzymes (Frankel, 1995). Some evidence suggests that the biological actions of these compounds are related to their antioxidant activity (Gryglewski et al., 1987).

Clematis brachiata Thunb, commonly known as Traveller's joy, is a deciduous climber that grows up to 5 $\mathrm{m}$ high belonging to Ranunculaceae family. It tends to clamber to the tops of trees and shrubs, sprawling over the crowns. Leaves are compound with from 1 to 7 leaflets.

*Corresponding author e-mail: drmostafabcsir@yahoo.com 
Attractive fragrant flowers appear in summer. Achenes are covered in fine silky hair. It is widely distributed in South Africa, Swaziland, Namibia and Botswana. Several species of the genus Clamatis have been widely used for folk medicine in many countries of the world. The decoction of the fruits and leaves of Clematis vitalba $\mathrm{L}$. for the treatment of mouth inflammation and rheumatic pain in Italy (Pieroni et al., 2004; Loi et al., 2004) and the leaves of Clematis drummondi $\mathrm{T} \& \mathrm{G}$ used as a disinfectant and antibiotic in Mexico (Cantrell et al., 1998). The infusion of the leaves and stem bark is used for treating schistomiasis in South Africa (Spang et al., 2000). Ethnomedicinal information from the indigenous people of the Eastern Cape Province revealed that the leaf extract is also used as a remedy for eye infection, skin disorder and wounds (Pendota et al., 2008). The antimicrobial activity of $C$. hirsuta Perr \& Guill. leaves and C. vitalba L. (Cos et al., 2002; Khan and Kihara, 2001), antifungal activity of the aerial part of $C$. drummondu T \& G. (Alanis-Garza et al., 2007) as well as antibacterial activity of the aerial part of $C$. cirrhosa L. (Tosun et al., 2004) have been reported. We had earlier been reported the antimicrobial activity, toxicity as well as anti-inflammatory, analgesic and anti-pyretic properties of C. brachiata leaves (Mostafa et al., 2013, 2009, 2010). Literature survey showed, there is no information on the antioxidant activities as well as total phenolic and flavonoids contents of Clamatis brachiata leaves. Therefore, the present study is an attempt to evaluate the antioxidant activity, total phenolics and total flavonoids contents of the different extracts of $C$. brachiata leaves.

\section{Materials and methods}

\section{Plant material}

Clematis brachiata was collected from a natural population within the premises of the University of Fort Hare, Alice, South Africa. The plant was identified by Prof DS Grierson of the Department of Botany, University of Fort Hare. A voucher specimen (M. Mostafa med. 2008/1) was prepared and deposited at the Giffen Herbarium of the University.

\section{Preparation of extract}

The dried leaves of the plant were pulverized and portions of $50 \mathrm{~g}$ each were separately extracted in hexane, acetone, methanol and water for $24 \mathrm{~h}$ on an orbital shaker (Stuart Scientific Orbital Shaker, UK). The extracts were filtered using a Buchner funnel and Whatman no. 1 filter paper. The acetone and methanol extracts were evaporated to dryness under reduced pressure at $40^{\circ} \mathrm{C}$ using a vacuum rotary evaporator (Laborot 4000-efficient, Heldolph, Germany), while the water extract was freeze-dried with Savant Refrigerated Vapor Trap (RVT4104, USA).

\section{Antioxidant activity}

\section{DPPH free radical scavenging assay}

The radical scavenging activities of the extracts on DPPH radical was determined by using the method described by Liyana-Pathirana and Shahidi (2005), with slightly modification. Briefly, one $\mathrm{ml}$ of DPPH solution $(0.135 \mathrm{mM})$ in methanol was mixed with one ml of varying concentrations of the extracts. The reaction mixture was vortexed thoroughly and left in the dark at room temperature for $30 \mathrm{~min}$. The absorbance of the mixture was read at $517 \mathrm{~nm}$ using butylated hydroxytoluene (BHT) as standards. A blank solution was prepared containing the same amount of methanol and DPPH. The ability to scavenge DPPH free radical was calculated from the expression: (\%) DPPH radical scavenging activity = $\left[\left(\mathrm{Abs}_{\text {control }}-\mathrm{Abs}_{\text {sample }}\right) /\left(\mathrm{Abs}_{\text {control }}\right)\right] \times 100$, where $\mathrm{Abs}_{\text {control }}$ was the absorbance of DPPH radical + methanol and $\mathrm{Abs}_{\text {sample }}$ was the absorbance of DPPH radical + sample extract/ standard. The $\mathrm{IC}_{50}$ (the concentration of sample required to decrease the absorption at $515 \mathrm{~nm}$ by $50 \%$ ) was calculated to quantify the antioxidant activity (Table I).

\section{ABTS radical scavenging assay}

The method described by Re et al. (1999) was adopted for the ABTS radical scavenging assay. The stock solution (equal volumes of $7 \mathrm{mM}$ ABTS salt and $2.4 \mathrm{mM}$ potassium persulfate) was allowed to stand in the dark for $14 \mathrm{hrs}$ at room temperature. The resultant $\mathrm{ABTS}^{+}$solution was diluted with methanol until the absorbance of $0.70 \pm 0.01$ at $734 \mathrm{~nm}$ was attained. Varying concentrations of the plant extracts $(1 \mathrm{~mL})$ was reacted with $1 \mathrm{ml}$ of the $\mathrm{ABTS}^{+}$solution and the absorbance read at $734 \mathrm{~nm}$ within 1-3 min using the spectrophotometer (Beckman DU-7000, USA) using butylated hydroxytoluene (BHT) as standards. The percentage inhibition was calculated from the expression: $(\%)$ ABTS radical scavenging activity $=\left[\left(\mathrm{Abs}_{\text {control }}\right.\right.$ $\left.\left.\mathrm{Abs}_{\text {sample }}\right) /\left(\mathrm{Abs}_{\text {control }}\right)\right] \times 100$, where $\mathrm{Abs}_{\text {control }}$ was the absorbance of ABTS radical + methanol and Abs sample $_{\text {was }}$ wa absorbance of ABTS radical + sample extract/ standard. The $\mathrm{IC}_{50}$ (the concentration of sample required to decrease the absorption at $734 \mathrm{~nm}$ by $50 \%$ ) was calculated to quantify the antioxidant activity (Table I).

\section{Determination of total phenolic}

The total phenolic content of the extracts was determined using the modified Folin-Ciocaltu method (Wolfe et al., 2003). Briefly, $1 \mathrm{~mL}$ extract $(1 \mathrm{mg} / \mathrm{mL})$ was mixed with $5 \mathrm{ml}$ 
Table I. Total phenolic, flavonoid and $\mathrm{IC}_{50}$ value of the leaf extracts of Clematis brachiata against DPPH and ABTS model. $(n=3, x \pm S D)$

\begin{tabular}{|c|c|c|c|c|}
\hline Extract & $\begin{array}{c}\text { Total } \\
\text { phenolic } \\
\left(\mathrm{mg} \mathrm{g}^{-1}\right)\end{array}$ & $\begin{array}{l}\text { Total flavonoids } \\
\qquad\left(\mathrm{mg} \mathrm{g}^{-1}\right)\end{array}$ & $\begin{array}{c}\mathrm{DPPH} \mathrm{IC}_{50} \\
\left(\mu \mathrm{g} \mathrm{mL}^{-1}\right)\end{array}$ & $\begin{array}{r}\operatorname{ABTS~IC~}_{50} \\
\left(\mu \mathrm{g} \mathrm{mL}^{-1}\right)\end{array}$ \\
\hline Acetone & $135.11 \pm 1.20$ & $65.58 \pm 0.60$ & $330.40 \pm 2.12$ & $130 \pm 1.4$ \\
\hline Methanol & $178.00 \pm 2.20$ & $36.37 \pm 0.36$ & $180.45 \pm 2.4$ & $60 \pm 0.80$ \\
\hline Water & $64.88 \pm 0.80$ & $10.03 \pm 0.40$ & $480.25 \pm 3.6$ & $170 \pm 0.75$ \\
\hline BHT & - & - & $80.60 \pm 0.60$ & $60 \pm 0.45$ \\
\hline
\end{tabular}

Folin-Ciocalteu reagent $(1: 10 \mathrm{v} / \mathrm{v}$ distilled water $)$ and $4 \mathrm{ml}$ $(75 \mathrm{~g} / \mathrm{L})$ of sodium carbonate. The mixture was vortexed for $15 \mathrm{~s}$ and allowed to stand for $30 \mathrm{~min}$ at $40^{\circ} \mathrm{C}$ for colour development. The absorbance was read at $765 \mathrm{~nm}$ with a spectrophotometer (Beckman DU 700, USA). Total phenolic content was determined as $\mathrm{mg}$ of gallic acid equivalent per $\mathrm{g}$ of dry extract using the equation obtained from a standard gallic acid calibration curve: $\mathrm{y}=6.993 \mathrm{x}+0.0379, \mathrm{R}^{2}=$ 0.9995 . where $\times$ is the absorbance and $y$ is the gallic acid equivalent (GAE). All the tests were performed in triplicate.

\section{Determination of total flavonoid}

Aluminium chloride colourimetric assay was used to determine the total flavonoid contents in the extracts as previously reported method described by Ordonez et al. (2006). Briefly $0.5 \mathrm{~mL}$ of $2 \% \mathrm{AlCl}_{3}$ was prepared in ethanol and was then added in $0.5 \mathrm{ml}$ of the extracts. The mixture was allowed to stand for $60 \mathrm{~min}$ at room temperature and the absorbance was read at $420 \mathrm{~nm}$ with a spectrophotometer (Beckman DU 700, USA). The extracts were evaluated at a final concentration of $0.1 \mathrm{mg} / \mathrm{mL}$. Total flavonoid content was calculated and expressed as $\mathrm{mg}$ of quercetin equivalent per $g$ of dry extract using the equation obtained from a standard quercetin calibration curve: $\mathrm{y}=43.862 \mathrm{x}-0.1757$, $\mathrm{R}^{2}=0.9931$. where $\times$ is the absorbance and $\mathrm{y}$ is the quercetin equivalent $(\mathrm{QE})$. All the tests were performed in triplicate.

\section{Results and discussion}

There are many different experimental methods by which the free radical scavenging activity can be estimated. One such method, by which total free radical scavenging can be evaluated, is by determining their efficiency to scavenge DPPH radicals. The DPPH, (2, 2 diphenyl-1-picryhydrazyl) is a stable free radical, which is widely used as a tool for estimating free radical-scavenging activities of antioxidants (Fenglin et al., 2004; Kim et al., 2002; Leong and Shui, 2002). The percentage of DPPH radical scavenging activity of the acetone, methanol and water extracts of $C$. brachiata leaves at different concentrations are shown in Fig 1. The concentration of each extracts required to inhibit 50\% DPPH free radical at $515 \mathrm{~nm}$ was calculated to quantify the antioxidant activities ( $\mathrm{IC}_{50}$ value) and was shown in Table $\mathbf{I}$. $\mathrm{IC}_{50}$ values were found to be $300.04 \mu \mathrm{g} / \mathrm{mL}, 180.45 \mu \mathrm{g} / \mathrm{mL}$ and $480.25 \mu \mathrm{g} / \mathrm{mL}$ for the acetone, methanol and water extract respectively. Among the studied extracts, the methanol showed the higher scavenging activity.

The ABTS radical cation scavenging assay is another widely used method to evaluate antioxidant activities. The percentage of inhibition of ABTS cation radical of the acetone, methanol and water extract at different concentrations are shown in Fig 2 . The concentration of each extracts required to inhibit 50\% ABTS cation radical was calculated to quantify the antioxidant activities $\left(\mathrm{IC}_{50}\right)$ and was shown in Table $\mathbf{I}$. $\mathrm{IC}_{50}$ values were found to be $130 \mu \mathrm{g} / \mathrm{mL}, 60 \mu \mathrm{g} / \mathrm{mL}$ and $170 \mu \mathrm{g} / \mathrm{mL}$ for the acetone, methanol and water extract respectively. Among the studied extracts, the methanol extract showed the higher scavenging activity at $60 \mu \mathrm{g} / \mathrm{mL}$. The methanol extract displayed antioxidant activity that is 


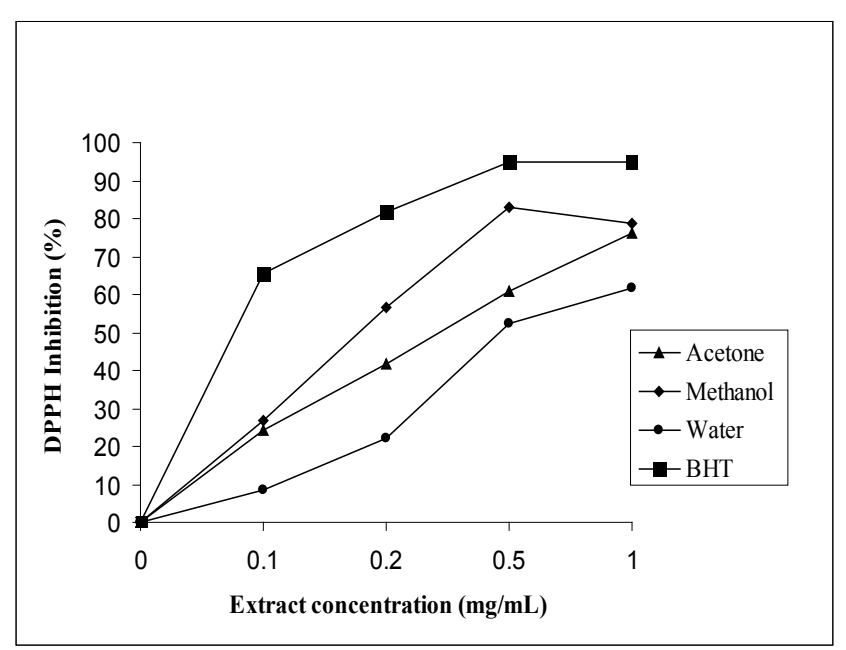

Fig. 1. DPPH free radical scavenging activity of the acetone, methanol and water extracts of the leaves of Clematis brachiata compared to Butylated hydroxytoluene (BHT) as standard antioxidant.

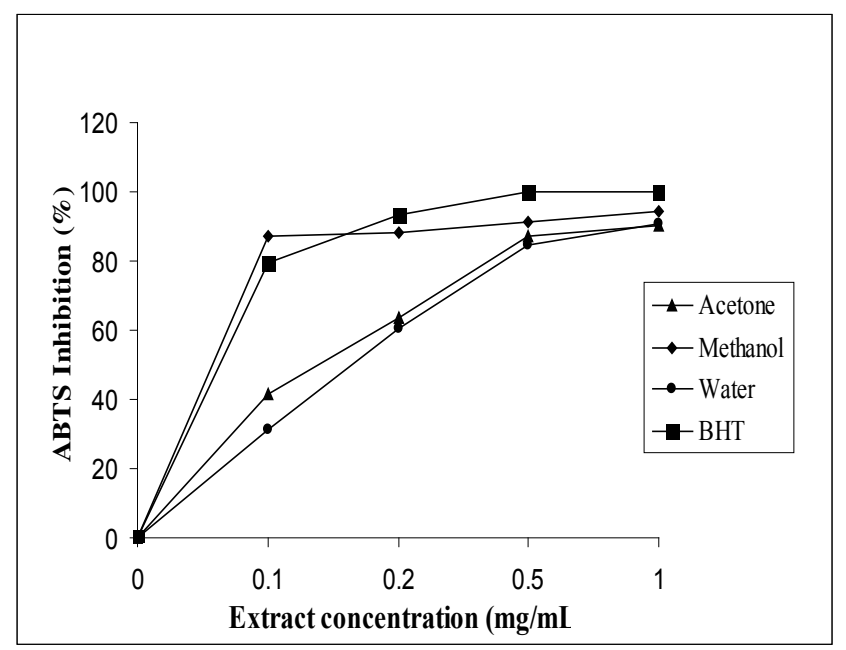

Fig. 2. ABTS scavenging activity of the acetone, methanol and water extracts of the leaves of Clematis brachiata compared to Butylated hydroxytoluene (BHT) as standard antioxidant.

similar to the reference compound, Butylated hydroxytoluene (BHT). The antioxidant activities decreased in the order of methanol, acetone and water in both DPPH and ABTS assays.

Total phenolic contents of different extracts of $C$. brachiata leaves were presented in Table $\mathbf{I}$. The total Phenolic (TP) content were found to be $135.11 \mathrm{mg} / \mathrm{g}, 178$ $\mathrm{mg} / \mathrm{g}$ and $64.88 \mathrm{mg} / \mathrm{g}$ of gallic acid equivalents per $\mathrm{g}$ of dry matter for the acetone, methanol and water extract respectively. The highest TP content was recorded in methanol extract while the lowest TP content was found in water extract. Total flavonoids contents of different extracts were presented in Table I. The total flavonoid (TF) were found to be $65.58 \mathrm{mg} / \mathrm{g}, 36.32 \mathrm{mg} / \mathrm{g}$ and 10.03 $\mathrm{mg} / \mathrm{g}$ of quercetin equivalents per $\mathrm{g}$ of dry matter for the acetone, methanol and water extract respectively. The highest level of TF was detected acetone extract while the lowest concentration was found in water extract.

Generally, total phenolic and flavonoids are groups of compounds that act as primary antioxidants (Samarth et al., 2008). These compounds possess a wide spectrum of chemical and biological activities including radical-scavenging properties. Studies have shown a strong relationship between total phenolic content and antioxidant activity in plants (Dorman et al., 2003; Velioglu et al., 1998). The phenols contain hydroxyls that are responsible for the radical scavenging effect mainly due to redox properties (Olayinka A, et al., 2010). On the other hand, the flavonoids compounds contain hydroxyl groups which are responsible for the radical scavenging activity (Das and Pereira, 1990). Plant phenolics and flavonoids have also been reported to have a lot of biological activities including inflammation, anti-carcinogenic, antioxidant and anti-mutagenic (Biju et al., 2014). The high antioxidant activities of methanol and acetone extracts might be due to their flavonoid and phenolic contents. Therefore, the antioxidant activity of these extracts of C. brachiata may explain its use to treat inflammations and wounds. The current investigation also confirmed that leaves of Clematis brachiata can be considered as potential natural antioxidants that play a major role in human health as free radical scavenger.

\section{Acknowledgment}

The authors acknowledge the support from the Govan Mbeki Research and Development Centre, University of Fort Hare, South Africa and the Bangladesh Council of Scientific and Industrial Research (BCSIR), Bangladesh.

\section{References}

Alan'is-Garza BA, Gonz'alez-Gonz'alez GM, Salazar-Aranda R, Waksman de Torres $\mathrm{N}$ and Rivas-Galindo VM (2007), Screening of antifungal activity of plants from the northern of Mexico, $J$ Ethnopharmacol. 114: 468-471. DOI: 10.1016/ j.jep.2007.08.026 
Biju J, Sulaiman CT, Satheesh G and Reddy VRK (2014), Total phenolics and flavonoids in selected medicinal plants from Kerala, Int J Pharma Pharm Sci. 6, 406-408.

Cadenas E and Davies KJA (2000), Mitochondrial free radical generation, oxidative stress and aging, Free Rad Biol Med. 29: 222-30. DOI: org/10.1016/ S0891-5849(00)00317-8.

Cantrell C, Fischer NH, Urbatsch L, Mcguire MH and Franzblau SG (1998), Antimycobacterial crude plant extracts from South, Central and North America, Phytomedicine 5: 137-145. DOI: 10.1016/ S09447113(98)80011-1.

Cos P, Hermans N, De Bruyne T, Apers S, Sindambiwe JB, Vanden Berghe D, Pieters L and Vlietinck AJ (2002), Further evaluation of Rwandan medicinal plant extracts for their antimicrobial and antiviral activities, J Ethnopharmacol. 79: 155-163. DOI: org/10.1016/ S0378-8741(01) 00362-2

Das NP and Pereira TA (1990), Effects of flavonoids on thermal autooxidation of Palm oil: structure- activity relationship, J Am oil Chem Soc. 67: 255-258. DOI: 10.1007/BF02540652

Dorman HJ, Kosar M, Kahlos K, Holm Y and Hiltunen R (2003), Antioxidant properties and composition of aqueous extracts from menthe species, hybrids, varieties and cultivars, $J$ Agric Food Chem. 51: 4563-4569. DOI:10.1021/jf034108k

Fenglin H, Ruili L, Bao H and Liang M (2004), Free radical scavenging activity of extracts prepared from fresh leaves of selected Chinese medicinal plants, Fitoterapia 75: 14-23. DOI:org/ 10.1016/ j.fitote.2003.07.003

Frankel E (1995), Nutritional benefits of flavonoids, International conference on food factors: Chemistry and Cancer Prevention, Hamamatsu, Japan. 6: 2.

Gryglewski RJ, Korbut R and Robak J (1987), On the mechanism of antithrombotic action of flavonoids, Biochemical Pharmacol. 36: 317- 321. DOI: 10.1016/0006-2952(87) 90288-7
Khan MR and Kihara M (2001), Antimicrobial activity of extracts of Clematis papuasica and Naucla obersifolia, Fitoterapia 72: 575-578. DOI: 10.1016/ S0367326X(01) 00258-12952(87)90288-7

Kim YK, Guo Q and Packe L (2002), Free radical scavenging activity of red ginseng aqueous extracts, Toxicology 172: 149-156. DOI: org/10.1016/S0300-483X (01) 00585-6

Leong LP and Shui G (2002), An investigation of antioxidant capacity of fruits in Singapore markets, Food Chem. 76: 69-75. DOI:org/10.1016/S0308-8146 (01)00251-5

Liyana-Pathiranan CM and Shadidi (2005), Antioxidant activity of commercial soft and hard wheat (Triticum aestivum L.) as affected by gastric $\mathrm{pH}$ conditions, $J$ Agric Food Chem. 53: 2433-2440. DOI: 10.1021/jf049320i

Loi MC, Poli F, Sacchetti G, Selenu MB and Ballero M (2004), Ethnopharmacology of Ogliastra (Villangrande Strisaili, Sardinia, Italy), J Ethnopharmacol. 95: 273-75. DOI:org/10.1016/j.fitote.2004.01.008

Mishra A, Bapat MM, Tilak JC and Devasagyam TPA, (2006), Antioxidant activity of Garcinia indica (kokam) and its syrup, Current Sci. 91: 90-93.

Mostafa M and Afolayan A (2013), Antimicrobial activity of Clematis brachiata Thunb leaf extracts, Int J Pharm Sci Res. 4(1): 243-247. DOI:org/10.13040 /IJPSR.0975-8232. 4(1).243-47

Mostafa M, Appidi JR, Yakubu MT and Afolayan A. (2010, Anti-inflammatory, analgesic and anti-pyretic properties of the aqueous extract of Clematis brachiata Thunb leaf in male Wistar rats, Pharm Biol. 48(6): 682-689. DOI: org/10.3109/13880200903257966

Mostafa M, Appidi JR, Yakubu.MT and Afolayan A J (2009), Toxicological implications of aqueous extract of Clematis brachiata Thunb leaf in male Wistar rats, $J$ Pharm Pharmacol. 3(11): 531-538.

Muthiah PL, Umamaheswari M and Asokkumar K (2012), In vitro antioxidant activities of leaves, fruits and peel extracts of Citrus, Int J Phytopharm. 2(1): 13-20. DOI:org/10.7439/ijpp.v2i1 
Olayinka A, Aiyegoro AI and Okoh (2010), Preliminary phytochemical screening and In vitro antioxidant activities of the aqueous extract of Helichrysum longifolium DC, BMC Complementary and Alternative Medicine, Oxford University Press. 10: 21. DOI:org/10.1016/j.foodchem.2005.05.024

Ordonez AAL, Gomez JD, Vattuone MA and Isla MI (2006), Antioxidant activity of Sechium edule (Jacq) Swart extracts, Food Chem. 97: 431-437.

Ozyurt D, Ozturk BD and Apak R (2004), Determination of total flavonoid content of Urticadioica L. by a new method, Adnan Menderes University, $4^{\text {th }}$ AACD Congress, Turkey.

Pendota SC, Grierson DS and Afolayan AJ (2008), An ethnobotanical study of plants used for the treatment of eye-infections in the Eastern Cape, South Africa, PakJ Biol Sci. 11: 2051-2053. DOI:10.3923/ pjbs.2008.2051.2053

Pieroni A, Quave CL and Santorod RF (2004), Folk pharmaceutical knowledge in the territory of the Dolomiti Lucane, inland southern Italy, $J$ Ethnopharmacol. 95: 373-384. DOI:org/ 10.1016/j.jep.2004.08.012

Re RN, Pellegrini A, Proteggente A, Pannala A, Yang M and Rice-Evans C (1999), Antioxidant activity applying an improved ABTS radical cation decolourization assay, Free Radical Biol Med. 26: 1231-1237. DOI:org/10.1016/S0891-5849(98)00315-3
Samarth RM, Panwar M, Manish K, Soni A, Madhu K and Ashok K (2008), Evaluation of antioxidant and radical scavenging activities of certain radioprotective plat extracts, Food Chem. 106: 868-873. DOI: org/10.1016/j.foodchem.2007.05.005

Spang SG, Van Staden J and Jäger AK (2000), Efficiency of traditionally used South African plants against schistosomiasis, J Ethnopharmacol. 73: 209-214. DOI: org/10.1016/S0378-8741(00) 00310-X

Tosun F, Akyuz-Kizilaya C, Senar B, Vural M and Palittapongarnpim P (2004), Antimycobacterial screening of some Turkish plants, J Ethnopharmacol. 95: 273-275. DOI:10.1016/j.jep.2004.07.011

Velioglu YS, Mazz, G, Gao L and Oamah BD (1998), Antioxidant activity and total phenolics in selected fruits, vegetables and grain products, J Agric Food Chem. 46: 4113-4117. DOI:10.1021/jf9801973

Wolfe K, Wu X and Liu RH (2003), Antioxidant activity of apple peels, J Agric Food Chem. 51: 609-614. DOI:10.1021/jf020782a 